\title{
Translation, Exile, and World Literature
}

\author{
The Livraria do Globo in Brazil
}

Urbi et Orbi (to the city and to the world) was the slogan of the Brazilian bookstore, later to become publishing house, the Livraria do Globo, founded in 1883 in Porto Alegre in southern Brazil ${ }^{1}$. During the twentieth century the Livraria do Globo, later Editora Globo, turned into one of the most important publishing houses alongside José Olympio ${ }^{2}$ and Editora Nacional - in Brazil. It was mainly responsible for the translation of foreign literature, especially English, French, Italian, and German, into Brazilian Portuguese. It began as a bookstore but turned into a publishing company in 1928. The name says it all: Globo, meaning globe, aimed at the internationalisation and globalisation of literature and developed a detailed concept of world literature and publishing strategies related to translation from the 1930s onwards. These strategies served as an example for the Brazilian book market in the twentieth century and were in large part responsible for the rise of foreign literatures in translation in Brazil. My contribution focuses on the parameters that determined the publishing house's successful development. I will therefore briefly focus on the rise of the Livraria do Globo, and then consider the determining criteria which made its publishing strategies so efficient. Among the criteria to be discussed are intellectual networks, politics of translation, and the connection between world literature and exile, which I will discuss in further detail through the example of the exiled translator and critic Herbert Caro.

\section{The Rise of the Livraria do Globo}

The history of the Livraria do Globo is discussed in a few reference works that deal with the publisher's rise, history, and development (De Amorim 2000, Ramos 2016, Rochadel Torresini 1999). When it was still a bookstore, Globo already focused on foreign - in this case mainly European - literature. It was,

1 For a detailed study of the history of the publisher, see Ramos (2016).

2 The publisher's archive is located at the Fundação Casa de Rui Barbosa in Rio de Janeiro.

Sonja Arnold, Deutsches Literaturarchiv Marbach

Ә Open Access. (C) 2021 Sonja Arnold, published by De Gruyter. (c) BY-NC-ND This work is licensed under a Creative Commons Attribution-NonCommercial-NoDerivatives 4.0 International License.

https://doi.org/10.1515/9783110713015-009 
for example, already possible to buy French literature, such as the works of Alexandre Dumas, Émile Zola, and Victor Hugo, in the nineteenth century (Ramos 2016: 58). However, these books were mere imports by French publishers in the language of origin. At that time, primarily French-Brazilian publishers of European literature in translation were virtually non-existent. These works were, therefore, only accessible to a small group of intellectuals who had mastered foreign languages. However, the existence of a small group of such intellectuals in Porto Alegre ${ }^{3}$ and their relationship to European publishers formed the very basis for a huge translation programme that came into being some decades later.

Although works of foreign literatures, and some of what was later called "world literature", had already been present in the bookstore, and on the publishing house's agenda, the rise of international literature in translation was still emerging. The movement was very much connected to two names, Érico Veríssimo and Henrique d'Ávila Bertaso, both of whom were responsible for Globo's publishing division in the 1930s and 1940s, and for initiating a huge programme for the translation of world literature into Brazilian Portuguese. Since most readers were not able to read the works in their original language, Mansueto Bernardi suggested a few key translations that were the basis of a large-scale translation programme from the 1930s onwards, making Globo the largest publisher of translated literature in Brazil (Ramos 2016: 70). After the departure of Mansueto Bernardi, Érico Veríssimo and Henrique d'Ávila Bertaso came onto the scene. The two launched major publishing programmes that greatly advanced Globo's work. Bertaso took a closer look at the few successful Brazilian publishers at that time, especially the publishing house José Olympio, and meticulously read Publishers Weekly to gain an overview of both publishing strategies and contemporary North American literature (Ramos 2016: 71). The translations owe their quality and selection to the Brazilian writer Érico Veríssimo, author of $O$ Tempo e o Vento (Time and the Wind). He was not only responsible for the selection and supervision of translations and translators, but was also a translator himself, and both chose the covers and prepared for the sale of the books. This is how James Joyce, Virginia Woolf, and William Faulkner were made available to the Brazilian market.

One of the publishing house's strategies was the creation of book series, which other publishing houses - like Suhrkamp, with its famous Bibliothek Suhrkamp or edition suhrkamp - took up in later years. This is how the Coleção

3 For a detailed panorama of the historical milieu, see Zalla (2015). 
Tucano (affordable paperback books comparable to Penguin paperbacks in the US), the Coleação Nobel (contemporary works of world literature, among them works by many Nobel laureates), the Biblioteca dos Seculos (classic works of world literature that were no longer under copyright), and the Coleção Amarela (Yellow Collection for crime novels, among others), came into being ${ }^{4}$.

From the 1940s onwards, systematic propaganda and innovative ways of ordering the books, for example by telegram (Lopes Lourenço Hanes 2019: 108), helped meet the requirements of the mass market. Between 1929 and 1967, the Revista do Globo, the publishing house's magazine, played a major role in distributing the new publications and translations, under the direction of Mansueto Bernardi, and later Érico Veríssimo. It aimed at distributing both international and local literature and culture, as was stated in the preface of the first edition:

Revista do Globo, porque se propõe registrar e divulgar, com o auxílio da Livraria do Globo, tudo o que no Rio Grande houver e doravante ocorrer digno de registro e divulgação. E ainda Revista do Globo porque deseja constituir uma ponte de ligação mental e social entre o Rio Grande e o resto do mundo (cited from Ramos 2016: 157)

It contained local and international news, contributions to economic, cultural, or political topics, short stories, poems, fashion, art and cinema, and was a platform for Brazilian artists, illustrators, and graphic artists ${ }^{6}$, as Paula Ramos has shown in her work, A Modernidade Impressa: Artistas Ilustradores da Livraria do Globo - Porto Alegre. Contributions alternated between local content, taking into account the history of independence efforts of the southern Brazilian state of Rio Grande do Sul, and global matters. This glocal strategy was very much connected to local intellectuals with international vitae, as well as to the urbanization process of the city of Porto Alegre in the first half of the twentieth century. As famous Brazilian contemporary writers had already been published by the José Olympio Press in Rio de Janeiro, the focus on local writers from Brazil's southern region can also be regarded as a strategic decision.

4 For a detailed discussion of these different book series, see Ramos (2016).

5 "Revista do Globo, because we intend to henceforth catalogue and distribute, with the help of the Livraria do Globo, everything in the Rio Grande do Sul culture, that is worthy of being catalogued and distributed. And also Revista do Globo, because we want to create a mental and social link between the Rio Grande region and the rest of the world" (my translation).

6 The Museum of Military Brigade (Museu da Brigada Militar) has a huge collection of the different numbers of the Revista do Globo (see Ramos 2016). 


\section{Intellectual Networks}

The publishing house's location, 268 Rua da Praia, was the coordinates of one of the most important meeting points in Brazilian cultural history in the first half of the twentieth century. Located in Porto Alegre's city centre and surrounded by cafés and restaurants, it served as a gathering place for intellectuals. One of the key figures was the aforementioned Brazilian author Érico Veríssimo, who worked as a journalist, translator, author and salesman at Globo. Many of the translations of foreign literature, for example the translation of works by Thomas Mann who he had met personally in Denver in $1941^{7}$, were suggested by Veríssimo. He was not, however, only interested in so-called high literature, but also opted for detective stories, light fiction, children's literature, and fairy tales ${ }^{8}$. In the 1930s, Johanna Spyri's Heidi, illustrated by João Fahrion, Treasure Island by R.L. Stevenson, Alice's Adventures in Wonderland by Lewis Carroll, and fairy tales by H.C. Anderson, illustrated by Nelson Boeira Faedrich, were published (Rochadel Torresini 1999: 85). In 1936-1937, Veríssimo wrote six books for children himself. The relationship between the illustrations of the books and the text played a major role, as Paula Ramos showed in her abovementioned study on illustrators at Globo. The illustrations of João Fahrion, Nelson Boeira Faedrich, and Ernst Zeuner became famous. The building on the Rua da Praia served as a meeting point for writers, illustrators, translators, and artists. Among them were local intellectuals like Érico Veríssimo and poet Mario Quintana, as well as exiled intellectuals, such as Herbert Caro. Intellectual networks of authors, artists, and illustrators, combined with good finances, made it increasingly possible to concentrate on works of international literature being made accessible to the Brazilian public through translation. In the legendary Sala dos Tradutores (translators' salon) publishers, editors, translators, and other people involved in the publishing process met to discuss questions of translation, as well as matters of sales and distribution.

7 For a detailed discussion of this connection, see Soethe (2014).

8 There was also a series in which world literature was made accessible to children, for example, Contos de Shakespeare, translated by Mario Quintana with illustrations by João Fahrion, as well as fairy tales by the Brothers Grimm, Alice in Wonderland, Heidi, and David Copperfield (see Ramos 2016: 353-433). 


\section{Politics of Translation - Sala dos tradutores}

Literature in translation was mainly published in two Globo collections: the Coleção Amarela (Yellow Collection) ${ }^{9}$, which was based on an idea by Henrique Bertaso. It was a collection of detective novels that included authors like Agatha Christie and Edgar Wallace. The other collection was the aforementioned Coleção Nobel (Nobel Collection). The different steps in the process of translation can be described as follows:

A) The selection of the texts: This was mainly based on the ideas of Bertaso and Veríssimo, who decided which texts were to be translated. However, they also relied both on their international intellectual networks, and on information by Publishers Weekly. This resulted in a slight preference towards British and North American literature (Lopes Lourenço Hanes 1999: 102).

B) The selection of the translators: During the 1930s and 1940s, Globo worked with a number of excellent translators, such as Manuel Bandeira, Carlos Drummond de Andrade, Cecilia Meireles, Mario Quintana (who translated $15 \%$ of the works in the Nobel Collection), and Érico Veríssimo, most of whom were also writers (dos Santos 2017; Reimão 2016). In fact, there was a preference for translators who were also authors. This preference was, at the same time, a strategy that was supposed to guarantee a high quality for the translated texts. Sheila Maria dos Santos pointed out the following correlation: "The works which were considered most important, were also the most likely to be translated by someone who was both a translator and a writer" (dos Santos 2017: 108).

C) How to translate and how to treat the translators: Up until 1947, the translators had a fixed salary, a whole library filled with dictionaries, and a platform for intellectual exchange in the Sala dos Tradutores, which provided a forum to discuss matters of translation at the Rua da Praia. After 1947, financial conditions no longer allowed for this special treatment (dos Santos 2017), and the status of the translator was downgraded, as is typical nowadays. However, the situation before 1947 represented a very special set of preconditions for literature in translation; one that was far removed from the marginalisation and disrespect of the translator as traduttore-traditore.

D) Place of publication and scope of the publication: One major strategy was to publish the translated works in book series. For example, the Coleção Nobel focused exclusively on translated literature. The translated works were supposed to be world literature distinguished either by the Nobel

9 For a detailed discussion of the Coleção Amarela, see Bottmann/Karam (2017). 
Prize or by other forms of success, such as high sales in their home country. The aim was to create a collection of international high literature. Most of these translations were published in the 1920s and 1930s a time period considered to be an Época de ouro da tradução, or the Golden Age of translation, specifically from 1931-1948, in Brazil (Chiarelotto 2016). Between 1931 and 1950, 338 books were translated and published at Globo (Chiarelotto 2016: 12).

\section{World Literature and Exile}

The intellectual surroundings, politics of translation, and contacts to European literature, culture, and art were also very much influenced by a number of exiled intellectuals in southern Brazil in the 1930s and 1940s. This was also reflected in the languages and cultural backgrounds of the selected texts. There was a clear preference for European and Anglo-American literature. The selected works were supposed to be the most important works of international high literature. The selection of certain world literature seemed to be a question of sales figures, too. This can be especially exemplified by taking a closer look at the selection criteria of the Coleção Amarela and the Coleção Nobel. In 1941, the Coleção Amarela changed its selection strategy as follows: "O método de seleção para a escolha dos livros que deverão aparecer na Coleção Amarela vai sofrer este ano uma reforma radical. Apenas romances policiais premiados nos Estados Unidos ou na Inglaterra serão editados" (Bottmann/Karam 2017: 178). ${ }^{10}$

Globo was criticised for this Eurocentric process of selection and was accused of neglecting Brazilian, and especially indigenous, literature (Rochadel Torresini 1999: 89). The focus on local literature from Rio Grande do Sul could, therefore, also be explained as an attempt to achieve a certain balance in the publishing house's programme. As Vanessa Lopes Lourenço Hanes (2019: 105) shows in her detailed analysis of some of Globo's translations, the target texts leave many words in the original language, English, and thereby characterise the works as "foreign". At the same time, by using the southern Brazilian tu instead of você, the texts can be clearly attributed to a Gaúcho translator and publisher. Once again, the publishing house creates its image as global and local at the same time. By taking a closer look at one of the translators who

10 "The method of selection for choosing the books which are to appear in the Yellow Collection will undergo a radical reform this year: Only crime novels with an award in the United States or in Britain shall be published" (my translation). 
brought the local and global together, I will discuss Globo's concept of world literature and its role in the process of translation in more detail.

\section{The Case of Herbert Caro}

The Jewish intellectual Herbert Caro worked as a lawyer, bookseller, table tennis player, translator, and journalist, and concurrently had extensive knowledge of music, art, and politics. He was born in Berlin in $1906^{11}$. When he was forbidden to work as a lawyer by the Nazis, he first emigrated to France - as many Jewish intellectuals did at the time - and then to Porto Alegre in 1934. Subsequently, he worked at the Globo publishing company in Porto Alegre, where he soon became friends with Érico Veríssimo, with whom he discussed translation and publishing issues. After acquiring sufficient knowledge of the Portuguese language, he started translating the works of Thomas Mann, Hermann Hesse, Elias Canetti, and many others (among them, six Nobel Prize winners) into Brazilian Portuguese. In addition, he contributed articles and essays to the Caderno de Sábado, a supplement of the journal Correio do Povo, where he wrote about German literature and culture, as well as about contemporary problems of Brazilian society. However, his point of view was never unidirectional; he never merely translated or projected German culture onto Brazil. Instead, he was always looking for the link between both cultures, as can be seen from his article "A mãe brasileira de Thomas Mann," translated “Thomas Mann's Brazilian Mother," where he traced the Brazilian roots of Thomas Mann's mother, Julia da Silva-Bruhns. He discovered traces of these biographical roots in the fictional works of both Heinrich and Thomas Mann, specifically in the character of Lola in Heinrich Mann's Zwischen den Rassen, Gerda Arnoldsen in Thomas Mann's Buddenbrooks, and Tonio Kröger's mother Consuelo.

Thomas Mann's mother, née Júlia da Silva Bruhns, later Julia Mann, spent the first years of her childhood as the daughter of a German merchant and a Brazilian mother in the state of Rio de Janeiro ${ }^{12}$. She traces these years in her autobiographical report Aus Dodos Kindheit, in which she talks about her memories of Brazilian flora and fauna, cultural peculiarities such as the Carnival and Brazilian musicality, as well as linguistic leftovers - her grandparents are called grossmãe and grosspai - that accompanied her throughout her life.

11 The remarks on Herbert Caro have partially already been published in Arnold (2017). For detailed studies on Herbert Caro, see also Arnold (2018).

12 On the Brazilian traces in the life and work of Thomas und Heinrich Mann see Kuschel/ Mann/Soethe (2009); Neumann (2007); Paulino/Soethe (2009), and Soethe (2014). 
These remnants are also reflected in the stories Julia Mann told her children (Mann 2017) and can be identified in the literary works of Thomas and Heinrich Mann $^{13}$.

Herbert Caro translated Thomas Mann's works Der Zauberberg, Die vertauschten Köpfe, Buddenbrooks, Der Tod in Venedig, and Tristan, as well as Klaus Mann's Mephisto, and works by other authors. These translations of Thomas Mann's texts are still widespread in Brazil today, as the new editions by the publisher Companhia das Letras from 2015 to 2017 show. It is interesting to note that Caro not only translated from his mother tongue into a foreign language, which is quite atypical for literary translation, but above all, reflected on his view of the act of translation as a new literary creation. He underpinned this view with theoretical reflections on his translational work, feuilletonist contributions, and correspondence with the authors he translated. Caro addressed the challenges of translating the works of Thomas and Klaus Mann in an essay entitled "Traduzir é conviver," or "Translating Means Co-existing," the title of which is quoted from the Brazilian author Guimarães Rosa, and in which he predicts a form of a conviviality among the literatures of the world at the intersection between different languages and cultures, that Ottmar Ette would later postulate.

The analysis of the brief but all-the-more revealing exchange of letters between Thomas Mann and Herbert Caro, which are located at the Jewish Cultural Institute in Porto Alegre (the ICJMC), reveals a complex panorama of the literary market at that time. In addition to strategic considerations and historical framework conditions, translations and their marketing are crucial cornerstones of cultural exchange.

In 1942, Caro had already translated Buddenbrooks, and had even contacted Thomas Mann in order to ask him about a problem concerning the translation, namely how the question of dialects could be resolved. This method was not uncommon for Caro; he had already contacted Elias Canetti, and the two of them discussed major problems and decisions concerning the Portuguese translation in the letters they exchanged. In his letter to Mann, Caro labels Mann's novel as Weltliteratur, or world literature, using the concept as a quality criterion.

13 Few researchers have taken up the Brazilian traces in the work of Thomas and Heinrich Mann. One of the most important reference works is Kuschel/Mann/Soethe (2009). In addition, Thomas Mann's text "Das Bild der Mutter" (1930) and his intensive correspondence with the Austrian director Karl Lustig-Prean, exiled in São Paulo, and leader of the movement "Das andere Deutschland-Brazil" (Movimento dos Alemães Livres do Brasil), as well as Mann's Brazilian reading traces, including the manuscript of Marte Brill's Brazilian exile novel, Schmelztigel, have been intensively researched (see Paulino/Soethe 2009). 
However, the very act of translation, and the blending of two cultural and linguistic horizons within this process, suggest a more modern concept of what world literature is. In his letter to Thomas Mann, Caro makes use of both conceptions of world literature. He first points out the universal characteristics of Buddenbrooks, "mit ihrem tiefen menschlichen Gehalt," or with its deeply human content, but then mentions the reception of the content in a Brazilian context:

Gewiss ist in diesem jungen und vorerst traditionslosen Land vieles fremd, was in diesem ungewöhnlich deutschen und norddeutschen Buch enthalten ist. Mancher Leser wird in ihm etwas von dem Reiz exotischer Fremdheit finden, den auf den Europäer Schilderungen fremder Länder ausüben. Andere werden vielleicht darüber hinaus imstande sein, die psychologische Tiefe dieses herrlichen Romans zu erfühlen (Caro 2007 [1941]: 72) ${ }^{14}$

The mentioned exoticism turns into a reciprocal experience and is no longer limited to a colonial perspective. It rather serves as filter for perception for the other side as well. Mann's novel is considered to be world literature not only because of its outstanding quality, but also because it is placed within the context of its international reception. It becomes world literature, not by its intrinsic qualities, but because of the mode of reading (Damrosch 2003). The German author confirms the different requirements needed for reception in his response to Caro. The two intellectuals discuss the best strategy to introduce Mann's work to the Brazilian market:

Zwar ist hier in den Vereinigten Staaten die Wirkung des "Magic Mountain” eine viel stärkere als die von "Buddenbrooks", aber ich bin mit Ihnen überzeugt, dass der bürgerliche Roman für ein südamerikanisches und literarisch vielleicht weniger gut vorbereitetes Publikum leichter zugänglich ist und besser zu meiner Einführung als Schriftsteller dienen kann (Mann 1990 [1942]: 111) ${ }^{15}$

Caro seems to be quite aware of the several sides of world literature, which include market strategies as well as editorial and economic decisions.

14 "Much of the content of this typically German or northern German book will be strange to this young country, which is devoid of tradition in the first place. Some readers will find the charm of exotic otherness in it, which descriptions of strange countries usually evoke in Europeans. Others will go beyond this and will be able to perceive the psychological profundity of this wonderful novel" (my translation).

15 "Although the effect of the Magic Mountain is much greater than that of Buddenbrooks, I am convinced that this bourgeois novel is much more accessible to a South American public that has little experience with literature and can therefore better serve as my introduction as a writer" (my translation). 


\section{Conclusion}

The circulation of books, their production, marketing, reception, and translation can be used to identify important stages in the cultural history of exile. It is therefore interesting to focus on publishing houses and their archives. The case of Globo reveals the complex threads that came together in the development of a successful programme of literary translation. The burgeoning city of Porto Alegre, with its intellectuals and important visionaries with international vitae, allowed for an extensive programme of translated world literature. The publishing houses relied on their intellectual networks, publishing strategies, and local strategies against the backdrop of a growing mass market. The example of the exiled translator Herbert Caro illustrates the importance of intellectual networks, as well as the transcultural and translingual elements at play in the process of translation. Looking at publishing archives in particular, teaches us that the discussion about global literary and cultural mediation can only be conducted on a global and highly connective level. The history of the Globo publishing house, together with its editorial strategies and translations, would therefore be worth reconstructing in more detail in order to provide important insights into aspects of Brazilian literary history on a global level.

\section{Works Cited}

Arnold, Sonja (2018): “Von deutsch-brasilianischer Literatur zur Transkultur. Weltliteratur, Exil und Globale Archive”. In: Germanistische Mitteilungen 44, pp. 79-94.

Arnold, Sonja (2017): "German Literature in Brazil. Writing and Translating between Two Worlds”. In: Cadernos de Tradução. Special Issue: Moving Bodies across Transland, 37/1, pp. 188-207.

Bottmann, Denise/Karam, Sérgio (2017): “A Coleção Amarela da Livraria do Globo (1931 -1956)". In: TradTerm 30, pp. 159-188.

Caro, Herbert (2007): “Letter to Thomas Mann, 14.10.1941. ICJMC, Porto Alegre.” In: Revista Contingentia 2, <https://www.global-archives.de/fileadmin/redakteure/brasilien/user_ upload/Documentos_do_Arquivo_Herbert_Caro.pdf> (last visit: 18/12/2019).

Chiarelotto, Arivane Augusta (2016): "A literatura italiana e os entrelaçamentos culturais da Editora do Globo: as traduções em questão". In: Mutatis Mutandis 9/1, pp. 5-19.

Damrosch, David (2003). What Is World Literature? Princeton: Princeton University Press. De Amorim, Sônia Maria (2000): Em Busca de um Tempo Perdido. Edição de Literatura Traduzida da Editora Globo (1930-1950). São Paulo: Editora da Universidade de São Paulo. Kuschel, Karljosef /Mann, Frido/Soethe, Paulo (2009): Mutterland - die Familie Mann und Brasilien. Düsseldorf: Artemis \& Winkler.

Lopes Lourenço Hanes, Vanessa (2019): “The Colonial Reverberations of Livraria do Globo Translations in 1930s Brazil”. In: Cadernos de Tradução, 39, 2, pp. 95-115. 
Mann, Thomas (1942): “Letter to Herbert Caro, 05. 05.1942.ICJMC Porto Alegre”. In: Wysling, Hans (eds.): Thomas Mann Selbstkommentare: "Buddenbrooks". Informationen und Materialien zur Literatur. Frankfurt: M.: Fischer 1990, pp. 111.

Mann, Viktor (2017): Wir waren fünf. Bildnis der Familie Mann. 5th edition. Konstanz: Südverlag.

Neumann, Gerson Roberto (2007): “Conhecendo Herbert Caro”. In: Revista Contingentia 2, pp. 23-28.

Paulino, Sibele / Soethe, Paulo (2009): "Thomas Mann e a cena intelectual no Brasil. Encontros e desencontros”. In: Pandaemonium Germanicum 14/2, pp. 28-53.

Ramos, Paula (2016): A Modernidade Impressa. Artistas Ilustradores da Livraria do Globo - Porto Alegre. Porto Alegre: UFRGS Editora.

Reimão, Sandra (2016): “Semblanze de Editorial Globo (1928-)”. In: Biblioteca Virtual Miguel de Cervantes: Portal Editores e Editoriales Iberoamericanos (siglos IXI - XXI), pp. 1-3.

Rochadel Torresini, Elisabeth (1999): Editora Globo. Uma aventura editorial nos anos 30 e 40. São Paulo: Editora da Universidade de São Paulo.

Dos Santos, Sheila Maria (2017): “Os Escritores e a Tradução na Editora Globo entre as Decadas de 1930 e 1960". In: Belas Infiéis 6/2, pp. 105-115.

Soethe, Paulo (2014): “Eine Begegnung in Denver: Thomas Mann, Érico Veríssimo - und Herbert Caro als Überbringer”. In: Müller, Gesine (Ed.): Verlag Macht Weltliteratur. Lateinamerikanisch-deutsche Kulturtransfers zwischen internationalem Literaturbetrieb und Übersetzungspolitik. Frankfurt: Tranvia, pp. 133-145.

Zalla, Jocelito (2015): "O Rio Grande da Globo: temporalidades regionalistas e edição de livros (1924-1960)”. In: História Unisinos 19/3, pp. 313-324. 
